University of Maine School of Law

University of Maine School of Law Digital Commons

\title{
Reform Through Resignation: Why Chief Justice Roberts Should Resign (in 2023)
}

Scott P. Bloomberg

University of Maine School of Law

Follow this and additional works at: https://digitalcommons.mainelaw.maine.edu/faculty-publications

Part of the Judges Commons, Law and Politics Commons, Law and Society Commons, Legal

Biography Commons, Rule of Law Commons, and the Supreme Court of the United States Commons

\section{Recommended Citation}

Scott Bloomberg, Reform Through Resignation: Why Chief Justice Roberts Should Resign (in 2023), 106 IOWA L. REV. ONLINE 16 (2021).

This Article is brought to you for free and open access by the Faculty Scholarship at University of Maine School of Law Digital Commons. It has been accepted for inclusion in Faculty Publications by an authorized administrator of University of Maine School of Law Digital Commons. For more information, please contact mdecrow@maine.edu. 


\title{
Reform Through Resignation: Why Chief Justice Roberts Should Resign (in 2023)
}

\author{
Scott Bloomberg*
}

\begin{abstract}
Many proponents of reforming the Supreme Court have expressed support for adopting a system of eighteen-year staggered term limits. These proposals, however, are hobbled by constitutional constraints: Amending the Constitution to implement term limits is highly implausible and implementing term limits through statute is likely unconstitutional. This Essay offers an approach to implementing term limits that avoids these constitutional constraints. Just as President Washington was able to establish a de facto Presidential term limit by not seeking a third term in office, Chief Justice Roberts is uniquely positioned to establish a new norm of serving eighteen-year terms on the Court. As this Essay will explain, the Chief Justice's well-timed resignation presents the most plausible path to Supreme Court term limits.
\end{abstract}

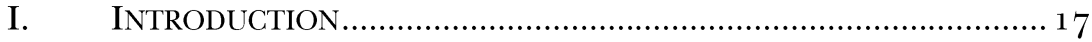

II. Institutional Problems Attendant to Life Tenure............. 19

III. The Proposed EighteEn-YeAR STAGgered TERM-LIMIT

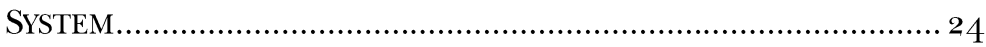

IV. IMPLEMENTING TERM LIMITS THROUGH A WELL-TIMED

RESIGNATION ................................................................... 33

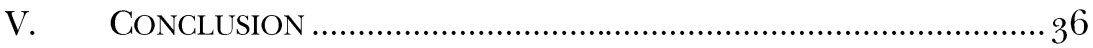

* Associate Professor of Law, University of Maine School of Law. I am indebted to Jeff Maine, Anthony Moffa, Cheryl Saniuk-Heinig, and Blake McCartney for their help in developing this project. I also thank the staff at the University of Iowa Law Review Online for their excellent editorial work. All errors are my own. 


\section{INTRODUCTION}

On September 29, 2023, Chief Justice Roberts will have served exactly eighteen years on the Supreme Court. ${ }^{1}$ He should mark this occasion by doing something extraordinary: resigning. By doing so, the Chief Justice could create a new norm whereby Supreme Court Justices agree to serve staggered eighteen-year terms on the Court. The resulting de facto term limit would rectify the structural problems caused by life tenure and would strengthen an institution "facing an unprecedented legitimacy crisis in the wake of" three exceptionally controversial Supreme Court appointments by President Trump. ${ }^{2}$

The problems associated with life tenure and the benefits of term limits have long been recognized by Court observers (and, for that matter, by the Justices themselves). .3 Life tenure creates randomness in the timing of Supreme Court vacancies, allowing some Presidents to appoint several Justices in a single term in office and allowing the Justices to strategically time their retirements to ensure that an ideologically-aligned President will appoint their successor. Life tenure has also led to a drastic expansion in length of service on the Court, resulting in sitting Justices who are increasingly attenuated from the democratic process through which they were appointed and confirmed.4 President Trump's appointments of Justices Gorsuch, Kavanaugh, and Coney Barrett highlight all of these shortcomings. Each Justice was appointed in controversial fashion by a one-term President who lost the popular vote, and each is young enough that they could realistically serve on the Court for four decades.5 This perfect storm has led many Democrats to characterize the Court as having been "packed" by Republicans or as being "illegitimate," and has concomitantly led to calls for drastic reform. ${ }^{6}$

1. Chief Justice Roberts took his seat on the Court on September 29, 2005. See Current Members, SUP. CT. OF THE U.S., https://www.supremecourt.gov/about/biographies.aspx [https:// perma.cc/8gSY-ZY7M].

2. Daniel Epps \& Ganesh Sitaraman, How to Save the Supreme Court, 129 YALE L.J. 148,153 (2019) (arguing, in 2019, before the controversial appointment of Justice Coney Barrett, that the Court faced such a crisis); see also Suzanna Sherry, Our Kardashian Court (and How to Fix It), 106 IOWA L. REV. 181, 182 (2020) ("The Supreme Court is broken. Public confidence in the Court has dropped; both the institution and individual Justices are accused of playing politics with the Constitution by allowing ideology to trump the rule of law. Calls for change-everything from term limits to court-packing to impeachment-are increasing in volume. Some scholars and pundits warn of a crisis of legitimacy.").

3. See infra notes $5^{1-5} 5^{6}$ and accompanying text (discussing the widespread support for term limits); infra note 109 and accompanying text (discussing Justice Breyer's support for term limits); infra note 107 and accompanying text (discussing Chief Justice Roberts support for term limits early in his legal career).

4. For a discussion of these issues, see infra text accompanying notes $15^{-22}$.

5. For a discussion of President Trump's appointments of Justices Gorsuch, Kavanaugh, and Coney Barrett, see infra text accompanying notes 23-37.

6. See, e.g., Fawwaz Shoukfeh, Democrats Should Pack the Court-Republicans Did it First, HARV. POL. REV. (Nov. 17, 2020), https://harvardpolitics.com/pack-the-court [https://perma.cc /HNW3-MDLK] ("Republicans' packing of the Court has left Democrats with no other option 
A system of eighteen-year staggered term limits has frequently been proposed to remedy the structural flaws associated with life tenure, but this proposal carries a problem of its own: It likely cannot be implemented without amending the Constitution, and amending the Constitution is exceedingly impractical.7 Without an alternate way to implement the eighteen-year term limit proposal, its value as a potential Court reform is thus limited.

Fortunately, there is a way to implement term limits without running afoul of Article III's Good Behavior Clause ${ }^{8}$ and without needing to amend the Constitution. When George Washington declined to seek a third term in office, he created a de facto Presidential term limit that lasted for over $15^{\circ}$ years and was later constitutionalized via the Twenty-Second Amendment.9 In this Essay, I argue that Chief Justice Roberts is uniquely positioned to accomplish the same for the Court. His status as the Chief Justice, his ideological position in the Court's center, and his reputation as a committed institutionalist make it plausible that his colleagues would follow his lead in creating de facto term limits. Moreover, for Chief Justice Roberts, his resignation would secure a nearly unparalleled legacy in the pantheon of Supreme Court Justices.

This Essay proceeds in three parts. In Part II, I provide an overview of the institutional problems associated with life tenure, including: (a) the randomness of Supreme Court vacancies; (b) the expanded length of service on the bench caused by youthful appointees and increased life spans; and (c) the politicization of the Court and the associated increase in the contentiousness of confirmation hearings. Part II also argues that President Trump's three appointments to the Court have exacerbated these longstanding problems with life tenure.

Part III analyzes the proposal, supported by many scholars, to implement eighteen-year staggered term limits for the Justices. I defend the proposal against the criticism that it would fail to depoliticize the Court, that it would lead to judicial impropriety because the Justices would consider their postSCOTUS careers in deciding cases, and that it would create excessive doctrinal instability. However, I agree with another critique of the eighteenyear staggered term limit proposal: Amending the Constitution to implement

-there must be significant judicial reform.”); Elaine Godfrey, The Democrats' Supreme Court Hail Mary, ATL. (Sept. 24, 2020), https://www.theatlantic.com/politics/archive/2020/o9/dem ocrats-case-court-packing/616446 [https://perma.cc/Q9ZY-554L] (discussing the Democrats who have called for expanding or reforming the Court); Joe Concha, Pelosi: Amy Comey Barrett 'an Illegitimate Supreme Court Justice', HILL (Nov. 3, 2020, 2:12 PM), https://thehill.com/homenews /house/524259-pelosi-amy-coney-barrett-an-illegitimate-supreme-court-justice [https://perma .cc/M9HT-YLAD] (quoting Speaker Pelosi as calling Coney Barrett "an illegitimate Supreme Court justice").

7. The various scholars who have proposed eighteen-year staggered term limits are discussed infra Part III and the constitutionality of implementing term limits through statute is discussed infra text accompanying notes $72-100$.

8. U.S. CONST. art. III, $\S 1$ ("The Judges, both of the supreme and inferior Courts, shall hold their Offices during good Behaviour ....")

9. See U.S. CONST. amend. XXII, § I (establishing that " $[\mathrm{n}]$ o person shall be elected to the office of the President more than twice"). I discuss the presidential term limit norm infra Part IV. 
term limits is implausible and implementing term limits through statute is likely unconstitutional.

This conclusion leads me, in Part IV, to argue that the most plausible way to establish Supreme Court term limits is through changed norms. I argue that Chief Justice Roberts is uniquely positioned to establish the new norm of serving an eighteen-year term on the Court and I explain how his well-timed resignation could create this de facto term limit system. Part V briefly concludes the Essay.

\section{Institutional Problems Attendant to Life TEnURE}

The Supreme Court has always been somewhat of an enigma in our constitutional system. The Court's power of judicial review is deeply enmeshed in our constitutional fabric ${ }^{10}$ and that power carries long-established constitutional benefits. ${ }^{11}$ But vesting the power to invalidate the acts of the popularly-elected branches of government in an unelected slate of life-tenured judges creates a tension with democratic principles. ${ }^{12}$ This tension is cause for concern both for originalists-who might believe the Justices are discovering rights not specified in the Constitution's text-and for those who believe that the task of constitutional interpretation necessarily involves indeterminacy and subjective decision-making. In either scenario, there is something uncomfortable with a group of unelected and democratically unaccountable persons making subjective decisions about what the democratically-elected branches can and cannot do.

It is unsurprising, then, that calls for reforming the Supreme Court have persisted since the institution's infancy. ${ }^{13}$ Reformers from across the political spectrum have proposed to alter, in one way or another, the Court's structure to maximize the benefits of judicial review while minimizing its drawbacks. ${ }^{1}{ }^{4}$

10. See, e.g., Marbury v. Madison, 5 U.S. 197, 177 (1803) (establishing the Supreme Court's power to review the constitutionality of executive and legislative actions).

11. See, e.g., The Federalist NO. 78 (Alexander Hamilton), https://guides.loc.gov/federa list-papers/text-7 1-8o\#s-lg-box-wrapper-25493470 [https://perma.cc/T8VP-F 5 WG] (explaining the benefits of judicial review and proclaiming "that the courts were designed to be an intermediate body between the people and the legislature, in order, among other things, to keep the latter within the limits assigned to their authority").

12. See, e.g., JOHn Hart Ely, Democracy AND Distrust: A TheOry OF Judicial Review $4^{-5}$ (1980) (describing "the central function" and "the central problem" of judicial review as being that "a body that is not elected or otherwise politically responsible in any significant way is telling the people's elected representatives that they cannot govern as they'd like"); ALEXANDER M. Bickel, The Least Dangerous Branch: The Supreme Court AT the Bar of Politics 16-23 (1962) (describing this tension as the Court's "counter-majoritarian difficulty").

13. See, e.g., Letter from Thomas Jefferson to William Taylor Barry (July 2, 1822), https://founders.archives.gov/documents/Jefferson/98-o 1-02-2919 [https://perma.cc/TQP $2-$ Z6BP] (criticizing life tenure and proposing that "the future appointments of judges be for 4 . [sic] or 6. [sic] years, and renewable by the President \& senate" to "bring [the judges'] conduct, at regular periods, under revision and probation" and to "keep them in equipoise between the general and special governments").

14. See, e.g., infra notes $5^{1-5} 5^{6}$ and accompanying text (discussing the broad bi-partisan support for eighteen-year staggered term limits). 
The Supreme Court's structural problems are well established. First, by virtue of enjoying life tenure, the Justices have full control over when they may resign and (like the rest of us) they have no control over when they may die. Both of these facts mean that the number of Justices whom a given President gets to appoint is left entirely to happenstance. ${ }^{15}$ It also means that the Justices can strategically time their resignations to choose which President gets to appoint their replacement. Second, the average length of service on the Court has expanded significantly and the Justices are increasingly attenuated from the democratic majority by which they were confirmed. ${ }^{16}$ This is particularly concerning given the extraordinarily important questions of democracy and society that the Supreme Court is, increasingly it seems, asked to decide. Third, Supreme Court confirmations have become quite contentious and political. ${ }^{17}$ Many scholars see this as a negative and a reason

15. The most striking historical example of a President enjoying the good fortune to appoint a disproportionate number of Justices to the Supreme Court is that of Presidents William Howard Taft and Warren G. Harding. President Taft appointed five Justices to the Court, and also elevated Justice Douglass White from Associate Justice to Chief Justice, even though Taft served just one term in office. See Justices from 1789 to Present, SuP. CT. OF THE U.S., https://www .supremecourt.gov/about/members_text.aspx [https://perma.cc/ 7 HN6-2ZVN] (listing Taft's appointments of Justice Lurton, Justice Hughes, Justice Van Devanter, Justice Lamar, Justice Pitney, and Chief Justice White). Taft, a Republican, lost to President Woodrow Wilson, a Democrat, in the election of 1912 . Despite serving two terms in office, Wilson appointed only three Supreme Court Justices. Id. (listing President Wilson's appointments of Justices McReynolds, Brandeis, and Clarke). President Warren G. Harding, a Republican, then won the Presidency in 1920. Harding served just two years as President before his death, but in that half-term in office he managed to appoint four Justices to the Court. This included Harding's appointment of former President Taft to the Chief Justice position. Id. (listing President Harding's appointment of Justice Sutherland, Justice Butler, Justice Sanford, and Chief Justice Taft). The accidents of history that allowed two Republican Presidents to appoint nine Justices over a collective six years in office led to a Court that was badly out of step with the country by the time President Franklin D. Roosevelt, a Democrat, took office and began implementing his New Deal program. See, e.g., Steven G. Calabresi \& James Lindgren, Term Limits for the Supreme Court: Life Tenure Reconsidered, 29 HARV. J.L. \& PUB. POL'Y 769, 811 (2006) (citing the Taft and Harding appointments as being responsible for "the Court of the 'nine old men'" during the New Deal Era).

16. See, e.g., Calabresi \& Lindgren, supra note 15, at 809-13 (arguing that the Justices' increased duration of service on the Court leads to reduced democratic accountability and declaring that "[a] Supreme Court completely divorced from democratic accountability is an affront to the system of checks and balances"); see also Philip D. Oliver, Systematic Justice: A Proposed Constitutional Amendment to Establish Fixed, Staggered Terms for Members of the United States Supreme Court, 47 OHIO ST. L.J. 799, 810 (1986) ("When voters select a President, they select the person who, in addition to many other important duties, will name Justices to the Supreme Court. As voters have historically changed the occupants of the White House, they have, indirectly but inexorably, changed the makeup of the Court."); see also Epps \& Sitaraman, supra note 2, at ${ }_{15} 6$ (arguing that the Supreme Court lacks "democratic pedigree" and is "particularly countermajoritarian" because "the two"-and now, since Justice Coney Barrett's appointment, the three- "most recent additions to the Court were selected 'by a president and a Senate who represent the will of a minority of the American people" (quoting Michael Tomasky, Opinion, The Supreme Court's Legitimacy Crisis, N.Y. TIMES (Oct. 5, 2018), https://www.nytimes .com/2018/10/05/opinion/supreme-courts-legitimacy-crisis.html [https://perma.cc/FQF $5-\mathrm{U}$ DLB])).

17. See Calabresi \& Lindgren, supra note ${ }_{15}$, at 813 . 
for reform (though, as discussed below, I am not so sure that it is).${ }^{18}$ Perhaps these drawbacks explain why no state in the nation, and no other major country in the world, gives life tenure to their high-court judges. ${ }^{19}$ The Supreme Court of the United States is all alone in sustaining the relic of life tenure.

The appointments of Justices Gorsuch, Kavanaugh, and Coney Barrett have exacerbated these concerns and have thus prompted new calls for reform. All three were appointed by a President who lost the popular vote by approximately three million votes and served only one term in office. ${ }^{20}$ By contrast, Presidents Clinton, George W. Bush, and Obama each served two terms and each appointed only two Justices to the Court. ${ }^{21}$ The three Trump appointees were, furthermore, all around $5^{\circ}$ years old upon their confirmations. ${ }^{22}$ With expanding life spans, they could plausibly serve on the Court for 40 years or more. And, as any contemporaneous reader of this writing knows, their confirmations to the bench were extraordinarily contentious. Only a brief recounting of these events is necessary.

Justice Gorsuch was appointed by President Trump and confirmed by the Senate only after Senate Majority Leader Mitch McConnell refused to consider President Obama's nomination of Judge Merrick Garland. Senator McConnell's stated reason for refusing to consider Garland's nomination was that it came too close in time to the 2016 presidential election. ${ }^{23}$ President

18. See, e.g., Calabresi \& Lindgren, supra note 15, at 813-15 (discussing the increased politicization of the Supreme Court's confirmation process); Epps \& Sitaraman, supra note 2, at 173 (stating, as a criteria for judging the efficacy of Supreme Court reforms, that reforms should "depoliticize the Court [and] turn down the temperature of the nominations process" and asserting that term limits would not accomplish these ends).

19. See Erwin Chemerinsky, The Case Against the Supreme COUrT 311 (2014).

20. See 2016 Presidential Election Results, N.Y. TIMES (Aug. 9, 2017, 9:00 AM), https://www.nytimes.com/elections/2016/results/president [https://perma.cc/H3GH-PMZP] (showing that Hillary Clinton won the popular vote by approximately 3 million votes); Presidential Election Results: Biden Wins, N.Y. TIMES, https://www.nytimes.com/interactive/2020/11/og/us /elections/results-president.html [https://perma.cc/ $\mathrm{E}_{5}$ RG-TXT6] (showing that President Biden won the Electoral College and the popular vote).

21. President Clinton appointed Justice Ginsburg and Justice Breyer; President Bush appointed Chief Justice Roberts and Justice Alito; and President Obama appointed Justice Kagan and Justice Sotomayor. See Justices from I 789 to Present, supra note 15 (listing every Justice from 1789 to present, along with the President by whom they were appointed).

22. Justice Gorsuch was born on August 29, 1967, and took his seat on April 10, 2017. Justice Kavanaugh was born on February 12, 1965, and took his seat on October 6, 2018. Justice Coney Barrett was born on January 28, 1972, and took her seat on October 27, 2020. See Current Members, SUP. CT. OF THE U.S., https://www.supremecourt.gov/about/biographies.aspx [https :/ / perma.cc/89SY-ZY $7 \mathrm{M}]$ (listing the biographies of the current Justices of the Supreme Court).

23. See, e.g., Mitch McConnell \& Chuck Grassley, McConnell and Grassley: Democrats Shouldn't Rob Voters of Chance to Replace Scalia, WASH. POST (Feb. 18, 2016), https:/ /www.washingtonpost .com/opinions/mcconnell-and-grassley-democrats-shouldnt-rob-voters-of-chance-to-replace-scali a/2016/o2/18/e 5aegbdc-d68a-1 1 e 5-be 55-2cc3c1 e4b76b_story.html [https://perma.cc/BP 46 EKWP] ("Given that we are in the midst of the presidential election process, we believe that the American people should seize the opportunity to weigh in on whom they trust to nominate the next person for a lifetime appointment to the Supreme Court.”); Erin Kelly, GOP Senators Vow Not to Consider Garland to Fill Supreme Court Vacancy, USA TODAY (Mar. 16, 2016, $11: 37$ AM), https:// 
Obama nominated Garland on March 16, 2016, over seven months before Election Day. ${ }^{24}$ When President Trump nominated then-Judge Coney Barrett mere weeks before the 2020 presidential election,,25 McConnell and his Republican Senate colleagues reversed course, discovering a new constitutional principle that it is fine to confirm Supreme Court Justices close to an election when the Presidency and the Senate are controlled by the same political party. ${ }^{26}$ To Democrats-and to some Republicans ${ }^{27}$ - this about-face was not fair play. ${ }^{2} 8$

Justice Kavanaugh's confirmation process was contentious for a different reason. Following his appointment, Christine Blasey Ford alleged that Kavanaugh had sexually harassed her when the two were teenagers in $1982 .{ }^{29}$ Ford had evidence in support of her allegation, including notes from a couples therapy session in 2012 during which she discussed being "attacked by students 'from an elitist boys' school' who ... bec [a]me 'highly respected and high-ranking members of society in Washington." $3^{\circ}$ During the

www.usatoday.com/story/news/2016/og/16/gop-senators-vow-not-consider-garland-fill-suprem e-court-vacancy/81856428 [https://perma.cc/8VK3-99ZZ] (quoting Senator McConnell as stating that it was "important for the Senate to 'give the people a voice in the filling of this vacancy' by waiting until the next president takes office").

24. See Remarks By the President Announcing Judge Merrick Garland as His Nominee to the Supreme Court, The White House: President BARACK OBAma (Mar. 16, 2016, 1 1:04 AM), https:/ / obama whitehouse.archives.gov/the-press-office/2016/o3/16/remarks-president-announcing-judge-m errick-garland-his-nominee-supreme [https://perma.cc/FF8D-E8V6].

25. See Remarks By President Trump Announcing His Nominee for Associate Justice of the Supreme Court of the United States, The White House: President Donald Trump (Sept. 26, 2020, 5:04 PM), https://trumpwhitehouse.archives.gov/briefings-statements/remarks-president-trump-an nouncing-nominee-associate-justice-supreme-court-united-states/ [https://perma.cc/NZ $7 \mathrm{~K}-\mathrm{AT}$ DK] (announcing Justice Coney Barrett's nomination approximately five weeks before Election Day).

26. See, e.g., Russell Wheeler, McConnell's Fabricated History to Justify a 2020 Supreme Court Vote, BROOKINGS (Sept. 24, 2020), https://www.brookings.edu/blog/fixgov/2020/og/24/mcconn ells-fabricated-history-to-justify-a-2020-supreme-court-vote $\quad[\mathrm{https} / / /$ perma.cc/HJ7N-JN $4 \mathrm{Y}]$ (recounting Republicans' shifting argument regarding election-year Supreme Court confirmations and concluding that the claim is "fig-leaf history" that lacks "factual basis").

27. See, e.g., Rachel Ohm, Collins Votes No on Barrett's Confirmation, Says She Did Not Make Decision on Qualifications, PORTLAND PRESS HERALD (Oct. 27, 2020), https://www.pressherald .com/2020/10/26/collins-breaks-with-party-to-oppose-barrett-confirmation [https://perma.cc $/ 5 \mathrm{Y}_{72}$-GD6E] (quoting Republican Senator Collins as stating that "the decision on the nominee to fill the Supreme Court vacancy should be made by whoever is elected on November $3^{\text {rd"). }}$.

28. See, e.g., Grace Segers, Senate Judiciary Committee Approves Amy Coney Barrett's Nomination, CBS News (Oct. 22, 2020, 8:oo PM), https://www.cbsnews.com/news/amy-coney-barrett-senatejudiciary-committee-nomination-approved-democrats-abstain/ [https://perma.cc/H8PK-H27N] (quoting Senate Minority Leader Chuck Schumer as stating that "[t]he nomination of Amy Coney Barrett is the most illegitimate process I have ever witnessed in the Senate" and quoting Democratic Senator Dick Durbin as declaring that the Republicans' actions in advancing Coney Barrett's nomination "were "in violation of fair play"”).

29. See, e.g., Alana Abramson, Read the Letter from Christine Blasey Ford's Lawyers Requesting an FBI Inquiry into Kavanaugh Allegation, TIME (Sept. 18, 2018, 10:16 PM), https://time.com/5400 239/christine-blasey-ford-investigation-letter/[https://perma.cc/P3XR-G3BN].

3o. Emma Brown, California Professor, Writer of Confidential Brett Kavanaugh Letter, Speaks Out about Her Allegation of Sexual Assault, WASH. POST (Sept. 16, 2018, 9:28 PM), https://www.washing tonpost.com/investigations/california-professor-writer-of-confidential-brett-kavanaugh-letter-sp 
confirmation process, Kavanaugh faced probing questions about this event and about other incidents that allegedly occurred when he was in high school and college $.3^{1}$ The temperament he displayed in response to the questioning was widely criticized as not being "judicial." ${ }_{32}$ Ms. Ford's allegations, and Justice Kavanaugh's unmeasured response to them, led to a narrow $5^{\mathrm{o}-48}$ confirmation vote. 33

These events have left the Supreme Court institutionally battered, with many Democrats believing the Court's 6-3 conservative majority is constitutionally illegitimate. Speaker Pelosi has called Justice Coney Barrett an "illegitimate" Justice.34 Former Attorney General Eric Holder has similarly referred to the Supreme Court's conservative majority as "illegitimate." 35 President Biden, for his part, has proclaimed that the Court is "out of whack" 36 and formed a Presidential Commission to examine Court reform. 37

The Court does not wield the purse or the sword. $3^{8}$ The enforceability of its decisions depends on the other branches of the federal government, the states, and the People believing in its legitimacy and according it due respect.

eaks-out-about-her-allegation-of-sexual-assault/ 2o18/og/16/46982 194-b846-1 1 e8-94eb-gbd $5^{2}$ dfeg17b_story.html [https://perma.cc/XgAP-BDPP].

31. See, e.g., Supreme Court Nominee Brett Kavanaugh Sexual Assault Hearing, Judge Kavanaugh Testimony, C-SPAN (Sept. 27, 2018), https://www.c-span.org/video/?451895-2/supreme-courtnominee-brett-kavanaugh-sexual-assault-hearing-judge-kavanaugh-testimony [https://perma.cc $/ \mathrm{LB}_{5} \mathrm{C}$-PLEQ] (video of Justice Kavanaugh's testimony and questioning).

32. See, e.g., Lulu Garcia-Navarro, Kavanaugh's Temperament, NPR (Sept. 3o, 2018, 8:23 AM), https://www.npr.org/2018/o9/3o/653086714/kavanaughs-temperament [https://perma.cc /NL2F-FJXH] (criticizing then-Judge Kavanaugh's temperament during his confirmation hearing); Robert Barnes, As Kavanaugh is All But Confirmed, Questions Linger about His Judicial Temperament, WASH. POST (Oct. 5, 2018, 5:29 PM), https://www.washingtonpost.com/politics /courts_law/as-kavanaugh-is-all-but-confirmed-questions-linger-about-his-judicial-temperament/ 2018/10/05/998da822-c8c4-1 1 e8-9b1c-agof 1daae3o9_story.html [https://perma.cc/3ZgD-U AUC] (collecting criticisms of Justice Kavanaugh's temperament during his confirmation hearing).

33. PN2259- Nomination of Brett M. Kavanaugh for Supreme Court of the United States,

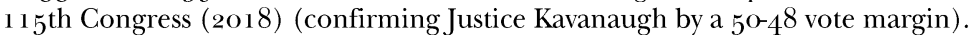

34. See Concha, supra note 6.

35. Khaleda Rahman, If GOP Creates 'Tllegitimate Majority'on Supreme Court, More Justices Should be Added: Former U.S. Attorney General, NEwsWEek (Sept. 20, 2020, 4:56 AM), https://www.news week.com/gop-supreme-court-eric-holder-1533125 [https://perma.cc/ZU2G-4RTE].

36. Biden Proposes Panel to Study Reforming 'Out of Whack' U.S. judiciary, Reuters (Oct. 22, 2020, 9:11 AM), https://www.reuters.com/article/us-usa-election-biden-court/biden-proposespanel-to-study-reforming-out-of-whack-u-s-judiciary-idUSKBN277238 [https://perma.cc/8WHC[FFD].

37. See President Biden to Sign Executive Order Creating the Presidential Commission on the Supreme Court of the United States, THE WHITE HOUSE (APRIL 9, 2021), https://www.whitehouse.gov /briefing-room/statements-releases/202 1/04/o9/president-biden-to-sign-executive-order-creat ing-the-presidential-commission-on-the-supreme-court-of-the-united-states / [https://perma.cc/ $\left.{ }_{5} \mathrm{~K}_{7} \mathrm{P}-\mathrm{ZJQ} 9\right]$ (announcing the Commission's formation and identifying the Commission's $3^{6}$ members).

38. The Federalist No. 78 (Alexander Hamilton), https://guides.loc.gov/federalistpapers/text-7 1-80\#s-lg-box-wrapper-25493470 [https://perma.cc/T8VP-F5WG] (describing the relative weakness of the judiciary as compared to the executive and legislative branches of government, and stating that the judiciary "has no influence over either the sword or the purse"). 
If the political party that represents more than half the country and now controls the other two branches of government believes the Court is not legitimate, or is not worthy of respect, then the Court has a problem.

\section{The Proposed Eighteen-Year StagGered Term-Limit System}

In view of these problems, several scholars have proposed Supreme Court reforms in recent years. 39 Most scholars have coalesced around a reform that involves each Justice serving a single eighteen-year term on the Court, with their terms being staggered by two years to ensure that every President can appoint two Justices per presidential term. $4^{\circ}$

The eighteen-year staggered term limit proposal originated in a 1986 law review article by Professor Philip Oliver.4 $4^{1}$ In Systematic Justice: A Proposed Constitutional Amendment to Establish Fixed, Staggered Terms for Members of the United States Supreme Court, Oliver proposes a constitutional amendment establishing the term limit system and specifying a procedure for replacing Justices who leave their terms early. $4^{2}$ This system of staggered term limits, Oliver argues, carries numerous benefits. It would remove the incentives Presidents have to appoint younger and younger Justices, 43 end the practice of Justices strategically timing their resignations to control which President appoints their successor, 44 and eliminate the disparity in Supreme Court appointments between Presidents.45 Oliver also frames life tenure as being democratically problematic in light of the inherent subjectivity involved in

39. Beyond the term-limit proposals discussed here, the most prominent recent reform proposal comes from Daniel Epps and Ganesh Sitaraman. They offer two reforms. The first is a "Supreme Court Lottery" "in which the Court would sit in panels selected at random from a large pool of potential Justices who would also serve as judges on the U.S. courts of appeals." Epps \& Sitaraman, supra note 2, at 181. Epps and Sitaraman would pair this reform with a 6-3 supermajority requirement for invalidating federal statutes (and potentially state statutes). Id. at 182 . The second is a "Balanced Bench" proposal in which the Court would be composed of five permanent Democratic-selected Justices, five permanent Republican-selected Justices, and five term-Justices unanimously selected by the ten permanent Justices. $I d$. at 193 . For a critique of these proposals, see Stephen E. Sachs, Supreme Court as Superweapon: A Response to Epps Eं Sitaraman, 129 YALE L.J. F. 93 (2019).

4o. See infra notes $4^{1,} 47$, and $5^{1}$ and accompanying text.

41. See Oliver, supra note 16 , at 8 oo.

42. Id. at $800-01$. Under the proposed amendment, if a Justice does not serve their full eighteen-year term, the President appoints a successor to serve the remainder of the term.

43. Id. at 803-04 (explaining that Presidents "have an incentive to choose a relatively young candidate" for the bench and that an eighteen-year term limit "would reduce any preference for very young candidates").

44. Id. at 805 (describing how Justices can strategically time their resignations and concluding "that this influence on the selection process by retiring Justices is wholly inappropriate").

45. Id. at 810-1 1 ("There is no great triumph of logic in a system under which, for example, President Nixon in five and one half years named four Justices, President Ford in two and one half years named one, and President Carter in four years named none. Despite being President for only a single term, President Taft named six Justices, more than any President in history with the exceptions of Presidents Washington and Franklin Roosevelt.") (footnotes omitted); $i d$. at 811 "Under the proposed amendment, each presidential election would carry with it the right to name two full-term Justices."). 
constitutional interpretation and he offers term limits as a way to mitigate this problem..$^{6}$

A 2004 student Note penned by James E. DiTullio and John B. Schochet expands upon Professor Oliver's proposal.47 The Note highlights how " $[\mathrm{t}]$ he increased involvement of the Supreme Court in a broad array of political issues has created" (or, I might suggest, exacerbated) the problems of strategic retirements, youthful appointees, and "the randomness of the distribution of ... Supreme Court appointments among presidents." 48 The Note also introduces, as an additional reason for implementing staggered term limits, the "increasingly contentious" confirmation process that grew from President Reagan's nomination of Judge Bork.49 DiTullio and Schochet argue that having shorter lengths of service and having regularly-timed vacancies would reduce the confirmation process's contentiousness in comparison to our existing system. $5^{\circ}$

Scholars from across the political spectrum have since called for imposing eighteen-year staggered term limits through constitutional amendment..$^{1}$ Erwin Chemerinsky, on the left, has written in support of the proposal. $.5^{2}$ Professors Calabresi and Lindgren, on the right, have too.53 The proposal's bipartisan support carries over to the political realm. Rick Perry

46. Id. at $799-800$ ("Individuals view the law differently. This is true even when they serve as judges, including service as Justices of the United States Supreme Court. . . The identity of the individuals who sit on the United States Supreme Court controls to a great degree the decisions and opinions rendered by the Court. . . It is not self-evident that the nation is best served by a system of life tenure for Supreme Court Justices.").

47. James E. DiTullio \& John B. Schochet, Note, Saving this Honorable Court: A Proposal to Replace Life Tenure on the Supreme Court with Staggered, Nonrenewable Eighteen-Year Terms, go VA. L. REV. 1093,1096 (2004).

48. Id. at 1096 .

49. Id. at 1098 .

5o. Id. at 1139 (arguing that staggered eighteen-year term limits have the "potential to mitigate or temper the acrimony that has arisen in the Senate surrounding the Supreme Court confirmation process"); $i d$. at 1141 ("[L]ife tenure raises the stakes of any Supreme Court confirmation battle beyond what they would be for a fixed-term appointment."); id. ("With regularity [in the timing of appointments] comes routine, and with routine comes less impassioned and more deliberative consideration of nominees.").

51. See, e.g., Sherry, supra note 2, at 194 n.61 (2020) (listing supporters of 18 -year staggered term limits); Christopher Sundby \& Suzanna Sherry, Term Limits and Turmoil: Roe v. Wade's Whiplash, 98 TEx. L. REv. 121, 122 (2019) (“[T] he idea of term limits has no clear ideological agenda and has been supported by scholars on both the left and the right.").

52. See Chemerinsky, supra note 19, at 310-12 (2014); Erwin Chemerinsky, Ted Cruz is Right: The Supreme Court Needs Term Limits, The New REPUBLIC (July 2, 2015), https://newrepub lic.com/article/ $122225 /$ ted-cruz-right-supreme-court-needs-term-limits [https://perma.cc/FT2 Z-ZDUG].

53. See Calabresi \& Lindgren, supra note 15 . 
has called for eighteen-year term limits.54 So has Andrew Yang.55 Public polling likewise shows widespread support for term limits in general..$^{6}$

This widespread support notwithstanding, the proposal has its critics. While a full response to term limits' detractors is beyond the scope of my work here, I do wish to respond to three critiques in particular. The first critique is that eighteen-year staggered term limits would fail to depoliticize the Supreme Court confirmation process. Professors Epps and Sitaraman make this argument in their innovative article, How to Save the Supreme Court, asserting that term limits would not "depoliticize the Court or turn down the temperature of the nominations process." 57 "[I]f anything," they argue, "it will make the politicization of the Court even worse by increasing the Court's prominence in every election cycle. ${ }^{5} 8$ Professor Sherry levels a similar critique of the proposal in her thoughtful work, Our Kardashian Court (and How to Fix It).59 She believes term limits may "mean that the Supreme Court becomes an issue for every presidential election, further politicizing the process."6o

I have a fundamental disagreement with this critique: The Supreme Court confirmation process should be politically contentious. The decision to be reached through that process is whether we should allow the nominee to become one of only nine people in the country that collectively serve as the final arbiter of our Constitution. That is an important decision. It should be at the forefront of every Presidential election and it should draw vigor from political opponents. This is particularly true under the Court's current lifetenure system. When the nominee is likely to serve on the Court for four-plus decades, rigorous scrutiny-and yes, contentiousness - is a valuable part of the democratic process for confirming that nominee. I would thus hope that Supreme Court nominations remain at the forefront of popular conscious during presidential elections (regardless of whether we adopt a system of term limits) ${ }^{61}$

Even if it is desirable to reduce the political contentiousness of the confirmation process, a system of staggered term limits would seem to

54. Mark Sherman, Some Want to Limit Justices to I 8 Years on Supreme Court, AssociATED PRESS (Feb. 18, 2016), https://apnews.com/article/5e2d2e278goe4adab88a7e24f2çfdog [https://p erma.cc/8DQC-JT7Q] (noting that Perry advanced an 18-year term limit during his 2012 Republican campaign for president).

55. I8 Year Term Limit for Supreme Court Justices, YANG 2020, https://www.yang2020.com /policies/scotustermlimits/ [https://perma.cc/7MY8-CSTH] (promising to "[p]ropose a constitutional amendment imposing 18-year term limits on Supreme Court Justices, with terms staggered so that there's one retirement every other year").

56. See Ryan C. Black \& Amanda C. Bryan, The Policy Consequences of Term Limits on the U.S. Supreme Court, 42 OHIO N.U. L. REV. 821, 822-23 (2016) (collecting public polling showing support for term limits ranging from $66 \%$ to $74 \%$ of the public).

57. Epps \& Sitaraman, supra note 2, at 173 .

58. Id.

59. Sherry, supra note 2.

6o. Id. at 194 (emphasis omitted).

61. By advocating for a rigorous and contentious confirmation process, I do not mean to suggest that the political parties should violate constitutional norms or other rules of fair play. Nor do I mean to suggest that the process should be mean-spirited. 
accomplish that. There is less at stake in confirming someone to the bench for eighteen years than in confirming someone for a lifetime. And, the minority party would know that it will have its own two bites at the apple if it is able to take the presidency in the next election cycle. It stands to reason that the comparatively lower stakes would lead to less contentiousness.

The second critique is that term limits would open the door for judicial impropriety, as Justices would reach decisions based in part to shape their career prospects upon leaving the bench. ${ }^{62}$ I would hope for better from our nation's highest judicial authorities, but this concern is, in any event, easy enough to remedy (or at least mitigate). Once a Supreme Court Justice finishes their eighteen years on the Court, they can continue to hold office as a federal judge and serve on circuit courts throughout the country as long as they want. ${ }^{3}$ Of course, the allures of politics or the private sector may attract the Justices instead. But this is already true. There is nothing currently preventing a Justice from retiring and then running for office or from joining a private enterprise.

The third critique of term limits is that it may increase doctrinal instability-i.e., the frequency with which the Court changes direction on a given issue over time. ${ }^{6}{ }_{4}$ Even under a system of life tenure, the Court has experienced a relatively high degree of doctrinal instability in some important lines of cases as its composition has changed in recent years. ${ }_{5}$ One possibility is that the increased turnover created by term limits will exacerbate this instability.

62. See Sherry, supra note 2, at 194-95 (" $[\mathrm{A}]$ term-limited Justice might instead try to make the most of his or her short time in office by courting favor even more assiduously-especially if he or she might want a post-retirement position at a political or quasi-political entity.”); Epps \& Sitaraman, supra note 2, at 174 ("A term-limited Justice might see the Court as the perfect jumping-off point for a presidential run, decide cases in hopes of retiring into a lucrative lobbying gig, or play to the public to secure a future on Fox News or MSNBC.”); David R. Stras \& Ryan W. Scott, Retaining Life Tenure: The Case for a "Golden Parachute", 83 WASH. U. L. Q. 1397, 1425 (2005) ("[F]ixed, nonrenewable terms, however, would introduce incentives for Supreme Court Justices to cast votes in a way that improves their prospects for future employment outside the judiciary.”).

63. This protection has already been proposed by advocates of the eighteen-year staggered term limit. See, e.g., Oliver, supra note 16, at 831-32 ("Another way of providing assurance of a Justice's independence while on the Court would be automatically to assure him a responsible position upon leaving the Court. The most reasonable position would be as a judge on a Circuit Court of Appeals, which position would still be life tenured. Since all Justices on the Supreme Court would be assured, for life, of highly prestigious judicial roles, it is difficult to see how their independence of action while on the Court could be in any way more secure than with life tenure on the Court itself.") (footnotes omitted).

64. See Sundby \& Sherry, supra note $5^{2}$, at 129.

65. The Court's campaign finance cases and its political gerrymandering cases serve as prime examples. Compare Austin v. Mich. Chamber of Com., 494 U.S. $65^{2}$ (199o), overruled by Citizens United v. Fed. Election Comm'n, $55^{8}$ U.S. 310 (2010) and McConnell v. Fed. Election Comm'n, 540 U.S. 93 (2003), overruled by Citizens United v. Fed. Election Comm'n, $55^{8}$ U.S. 310 (2010), with Fed. Election Comm'n v. Wisc. Right to Life, Inc., $55^{1}$ U.S. 449 (2007), Citizens United v. Fed. Election Comm'n, $55^{8}$ U.S. 310 (2010) and McCutcheon v. Fed. Election Comm'n, 572 U.S. 185 (2014). Compare Davis v. Bandemer, 478 U.S. 109 (1986), abrogated by Rucho v. Common Cause, 139 S. Ct. 2484 (2019), with Vieth v. Jubelirer, 541 U.S. 267 (2004), and Rucho v. Common Cause, 139 S. Ct. 2484 (2019). 
Professors Sherry and Sundby study this question in their essay, Term Limits and Turmoil: Roe v. Wade's Whiplash. ${ }^{66}$ Using Roe as a case study, they employ a statistical modeling approach to assess the level of instability eighteen-year staggered term limits may create. ${ }^{67}$ Their analysis indicates that the Justices' degree of deference to precedent-their respect for stare decisisis a significant variable in determining how the term-limit system would impact doctrinal stability. ${ }^{68}$ With no deference to precedent, Sherry and Sundby estimate that the Court would have switched positions on Roe three times between 1973 and 2020.69 Factoring even a minimal respect for stare decisis, their statistical model suggests the Court would have switched positions on Roe once during that time. $7^{\circ}$ "Deference to precedent, not surprisingly, appears to bring substantial doctrinal stability to a term-limit system." ${ }^{11}$

There is good reason to think that Supreme Court Justices operating under a system of staggered term limits would display at least slightly more respect for stare decisis than the current baseline. First, I expect the nation's top jurists would appreciate the potential for doctrinal instability created by the term-limit system and would act accordingly to prevent undesirable levels of instability from materializing. Second, when the ideological composition of the Court is likely to change in the future, the Justices have a self-interest in respecting stare decisis. If they do not follow precedents that they are ideologically inclined to disregard, why would a future Justice hesitate in overruling a case penned by the earlier-in-time Justice? By respecting stare decisis, the Justices increase the likelihood that their own opinions will remain good law when the Court's ideological composition shifts in the future. Currently, that incentive is much weaker for the ideologically conservative Justices who seem poised to prolong indefinitely their already long-held majority on the Court.

There is, however, a fourth critique of term limits with which I agree: implementing term limits through constitutional amendment is extraordinarily unlikely. Amending the Constitution is hard. You need to

66. Sundby \& Sherry, supra note 52. See also generally Black \& Bryan, supra note 56 (analyzing how the imposition of eighteen-year term limits would have impacted the Court's composition since 1937 and positing how term limits would have impacted some of the Court's key decisions).

67. Sundby \& Sherry, supra note 52 , at $138-58$.

68. See id. at $145^{-} 5^{\circ}$ (analyzing how adherence to stare decisis would impact doctrinal stability in the term-limit system).

69. Id. at 140 (explaining a statistical model that shows term limits would result in the Court reversing its stance on Roe "three times in only forty-six years," assuming the appointed judges have "moderate" levels of ideological alignment with the presidents by whom they are appointed).

7o. Id. at 147 (explaining that the Court would only switch positions on Roe once and concluding that "an adherence to stare decisis, even a weak one, does insert some degree of stability into the model"). Sherry and Sundby also conclude that too high of a level of adherence to stare decisis can also be problematic for term limits. If the Justices are too reluctant to overturn precedent, it could undermine "the very democratic responsiveness that makes term limits appealing to many proponents." Id. at $149-5$ o.

71. Id. at 149 . 
secure two-thirds of both houses of Congress and three-quarters of the states. $7^{2}$ It is beyond unlikely that the Republican Party would willingly relinquish the indefinite majority they now hold on the Court as a result of President Trump's appointments.73 And, even in a less hostile political climate than the one we are now enduring, getting the necessary super-majority to agree on a constitutional amendment would be a monumental undertaking.

While implementing term limits through constitutional amendment is extraordinarily unlikely, implementing them through statute is likely unconstitutional. The most well-known statutory proposal comes from Professors Carrington and Cramton.74 They believe that Congress can impose term limits on Supreme Court Justices without offending Article III's Good Behavior Clause if, at the end of the eighteen-year term, the Justices are allowed to continue their service on lower federal courts in their capacities as "Senior Justices."75 Their argument goes like this: Article III provides that "[t]he Judges, both of the supreme and inferior Courts, shall hold their Offices during good Behaviour." 76 This text does not specify whether the "office" of the judges of the Supreme Court is distinct from the "office" of the judges of the inferior courts. (To illustrate this ambiguity, consider how the addition of the term "respective" after the word "their" would clarify the scope of the phrase "their Offices." 77 ) Given the ambiguity, they believe Congress could create a judicial "office" that includes service on both the Supreme Court and on the inferior federal courts. Thus, under their proposal, when a Justice's eighteen-year term ends and the Justice loses their primary responsibilities on the Supreme Court, they would continue to hold their "office" as a federal judge for life (or until they resign or are impeached). $7^{8}$

72. U.S. CONST. art. V.

73. See, e.g., Epps \& Sitaraman, supra note 2, at 174 (noting that implementing term limits via constitutional amendment "would need significant Republican support, which seems highly unlikely for the foreseeable future").

74. See generally REFORMING THE COURT: TERM Limits FOR SUPREME COURT JUSTICES (Roger C. Cramton \& Paul D. Carrington eds., 2005) (discussing the consequences of lack of judiciary term limits); Roger C. Cramton, Reforming the Supreme Court, 95 CAL. L. REv. 1313 (2007) (discussing the implications of life tenure for Supreme Court Justices); Paul D. Carrington \& Roger C. Cramton, The Supreme Court Renewal Act: A Return to Basic Principles, PAULCARRINGTON.COM (July 5, 2005), http://paulcarrington.com/Supreme\%2oCourt\%2oRen ewal\% 20Act.htm [https://perma.cc/D $\left.5 \mathrm{~V}_{3}-\mathrm{EXKF}\right]$ (same).

75. See Cramton, supra note 74, at 1324-25 ("After completion of the period of service on the sitting Court, Justices would continue to serve in accordance with the Good Behavior Clause of Article III by performing judicial duties in circuit courts, much as Justices were required to do during most of the nineteenth century. If needed to provide a nine-member Court, the Senior Justice junior in commission would be recalled to the Court to serve until the next term of Congress, when the new appointment would be made. Senior Justices would also participate in the Court's procedural rulemaking authority ....").

76. U.S. CONST. art. III, $\$ 1$.

77. See Calabresi \& Lindgren, supra note ${ }_{15}$, at $86_{5}$ (positing that the Framers could have clarified the meaning of the Good Behavior Clause with this addition).

78. Cramton, supra note 74 , at $1933-34$. 
Although dozens of scholars have signed onto this proposal,79 its constitutionality is in significant doubt. One very thorough critique of Carrington and Cramton's proposal comes from Calabresi and Lindgren, who, after proposing an eighteen-year term limit statute of their own, conclude that both their own proposal and the Carrington-Cramton proposal are unconstitutional. ${ }^{80}$ Drawing from the text and structure of the Constitution, ${ }^{81}$ as well as " 217 years of actual practice" of treating the office of Supreme Court Justice as a separately-commissioned office, ${ }^{82}$ they reject Carrington and Cramton's position that the Good Behavior Clause contemplates a single "office" encompassing the Supreme Court and the inferior federal courts. ${ }^{83}$ Instead, "the office of Supreme Court Justice is a separate and distinct office to which nongermane lower federal court duties may not be attached." ${ }_{4}$ This conclusion sounds the death knell for any attempt to circumvent the Good Behavior Clause by allowing Justices to retain office on an inferior federal court following their term on the Supreme Court.

Perhaps the most convincing support for Calabresi and Lindgren's conclusion that Supreme Court term limits cannot be constitutionally imposed through such creative statutory schemes comes from their discussion of Article II's Appointments Clause. That clause states that the President "shall nominate, and by and with the Advice and Consent of the Senate, shall appoint ... Judges of the supreme Court ...." ${ }_{5}$ As Calabresi and Lindgren explain, "[g]iven that the Appointments Clause plainly contemplates a separate office of judge of the Supreme Court, it is hard to see how that office could constitutionally be filled for only eighteen years and not for life," in light of the Good Behavior Clause's life tenure requirement. ${ }^{86}$

Professors David R. Stras and Ryan W. Scott have also assessed the possibility of imposing term limits through statute and reached the same conclusion as Calabresi and Lindgren (on much the same grounds). ${ }^{8} 7$ Their conclusion rests on three pillars: (1) the Good Behavior Clause plainly

79. See The Supreme Court Renewal Act: A Return to Basic Principles, supra note 74 (listing over 4o signatories including Bruce Ackerman, Jack Balkin, Yale Kamisar, Sanford Levinson, Lawrence Tribe, Mark Tushnet, and numerous other widely respected scholars).

8o. See Calabresi \& Lindgren, supra note $1_{5}$, at 855 ("Because we conclude both [proposals] are unconstitutional, we believe instituting term limits will require a constitutional amendment ....").

81. See id. at 859-68 (analyzing the Good Behavior Clause, the Appointments Clause, the Chief Justice Presiding Clause, and the relation between these three clauses).

82. Id. at 864 .

83. Id. at 864-68 (evaluating Carrington and Cramton's interpretation of the Good Behavior Clause and concluding that their "argument that the Good Behavior Clause does not contemplate separate offices for Supreme and inferior courtfederal judges is too clever by half").

84. Id. at 867 .

85 . U.S. CONST. art. II, $\$ 2$.

86. Calabresi \& Lindgren, supra note $1_{5}$, at 859 .

87. See Stras \& Scott, supra note 62 , at 1467 . 
requires that the Justices be appointed to their offices for life;8 (2) "on a fair reading of its text and structure, the Constitution contemplates separate offices for judges of the Supreme Court and judges of the inferior courts," not a single office as Carrington and Cramton conclude; 89 and (3) Congress cannot eliminate the "essential powers and duties" of those offices-by stripping the Justices' power to decide Supreme Court cases-without running afoul of the Good Behavior Clause. $9^{\circ}$

I would add to these critiques two observations, one regarding constitutionality and one regarding efficacy. As to constitutionality, let us accept for purposes of argument that the Carrington-Cramton proposal presents a close constitutional question. Who would be tasked with deciding that close constitutional question? The Supreme Court, of course. I do not think it is going out on a limb to suggest that a majority of the Court would not be keen to let their co-equal branch impose term limits upon them, particularly if the ideology of the Court's majority does not align with the Congress that enacted the reform. In fact, a group of Democratic Representatives recently introduced a bill to implement eighteen-year staggered term limits. ${ }^{1}$ Perhaps I am just a cynic, but if the bill becomes law, it strikes me as highly unlikely that five of the current Supreme Court Justices will find the law constitutional.

But even if Congress could constitutionally impose term limits via statute, it could only do so prospectively. That is to say, even if Congress can limit future Justices to an eighteen-year term of active service on the Supreme Court, it would be a leap beyond credulity to conclude that Congress can also impose this condition on the current Justices. Carrington and Cramton recognize this limitation and accordingly include a clause in their proposed statute to delay its implementation until the last of the current Supreme Court Justices retires. $9^{2}$

That delay may have been tolerable when Carrington and Cramton originally proposed it. At that time, only one Justice-Justice Thomas-was not yet a senior citizen (he was $5^{6}$ ).93 Today, there are four Justices under 65

88. Id. at 1408 (concluding that " $[\mathrm{t}]$ he requirement that judges hold office 'during good behaviour' prevents Congress from directly creating term limits . . . for judges by statute”).

89. Id. at 1409 .

9o. Id. at $14^{1} 5$ ("Congress may not subtract from the responsibilities of an office in a way that deprives officers of the essential powers and duties of the office. For judges, those powers include adjudicating disputes that come before the court to which they are assigned." (emphasis in original)).

91. See Supreme Court Term Limits and Regular Appointments Act of 2020, H.R. 8424, 116 th Cong. (2020).

92. See The Supreme Court Renewal Act: A Return to Basic Principles, supra note 74 ("Justices sitting on the Court at the time of this enactment shall be permitted to sit regularly on the Court until their retirement, death, removal or voluntary acceptance of status as a Senior Justice.”).

93. Carrington and Cramton first proposed their statute at an academic conference in April 2005. Id. 
years old and three who are well under 60 years old.94 The youngest Justice is Amy Coney Barrett. She is 49 years old.95 If she serves until she reaches the same age as her predecessor, it would delay the implementation of Carrington and Cramton's statute for nearly forty years. $9^{6}$ Forty years is plenty of time for mischief, and some future Congress may well find it politically advantageous to repeal or otherwise impair the statute. 97 Forty years is also a costly delay for an institution in need of more immediate reform (and for anyone who would like to see that reform come before they are old and gray or are gone from this Earth).

If imposing term limits via statute is likely unconstitutional (and perhaps ineffectual), why have dozens of preeminent scholars signed on to the Carrington-Cramton proposal? The most probable explanation is that they like the idea of Supreme Court term limits, they recognize that constitutional amendment is exceedingly unlikely, and they see the statutory proposal as the more achievable of two moonshots. I see it that way too. Truth be told, I quite like the Carrington-Cramton proposal. I would sign on to support it. But my support would be for term limits in principle, not for the constitutionality of their proposed statute. I suspect this was the case for many of the venerable scholars who lent their names to the proposal. Indeed, the signature page to the proposal announces that the scholars support the proposal "in principle" and "in general terms." 98

In sum, neither constitutional amendment nor statutory enactment offer a plausible pathway to term limits. The implausibility of both approaches limit their value as mechanisms for reform. 99

Should reformers thus abandon eighteen-year staggered term limits in favor of more drastic reforms like the "Supreme Court Lottery" or the fifteen-member "Balanced Bench" approach offered by Epps and Sitaraman? ${ }^{100}$ I do not believe so. While those reforms deserve consideration, reformers should also pursue an alternative approach to implementing term

94. See Current Members, SuP. CT. OF THE U.S., https://www.supremecourt.gov/about/biog raphies.aspx [https://perma.cc/ $3 \mathrm{EFT}_{5} \mathrm{8F}_{3}$ ] (showing that Justice Kagan is 61 years old, Justice Kavanaugh is $5^{6}$ years old, Justice Gorsuch is 53 years old, and Justice Coney Barrett is 49 years old).

95. Id.

96. Her predecessor, Justice Ginsburg, served until she was 87 years old. See Linda Greenhouse, Ruth Bader Ginsburg, Supreme Court's Feminist Icon, is Dead at 87, N.Y. Times (Sept. 24, 2020), https://www.nytimes.com/2020/og/18/us/ruth-bader-ginsburg-dead.html [https://pe rma.cc/A3VP-N855].

97. See Calabresi \& Lindgren, supra note $1_{5}$, at 868 ("There is ... a key problem in the concept of establishing term limits through a statute, which is that term limits established by statute rather than by constitutional amendment are subject to greater manipulation by future Congresses.").

98. The Supreme Court Renewal Act: A Return to Basic Principles, supra note 74.

99. See, e.g., Epps \& Sitaraman, supra note 2, at ${ }_{15} 5^{2}$ (proposing, as criteria for evaluating Court reforms, that any reform "must be constitutionally plausible" and "must be capable of implementation via statute, given the near impossibility of a constitutional amendment in an age of severe polarization").

1oo. See id. at 181-200. (explaining both proposals). 
limits: creating de facto term limits through changed norms. Toward this end, I argue in Part IV that Chief Justice Roberts could-uniquely, among his peers-create de facto term limits by resigning after eighteen years of service on the Supreme Court.

\section{IMPLEMENTING TERM LIMITS THROUGH A WELL-TIMED RESIGNATION}

People in positions of great power voluntarily leave office for a number of reasons. They may cede power due to declining health, or to unhappiness, or just because they want to do something else with their time. Far more rarely, they leave office for the greater good of their institution. It takes an extraordinary person to recognize that vacating their office may be necessary to preserve or strengthen their institution.

The most famous example in American lore comes from our first President. George Washington voluntarily declined to seek a third term in office (in the election of 1796 and again in the election of 1800 ), creating a de facto two-term limit that persisted for over $15^{\circ}$ years. ${ }^{101}$ After President Franklin D. Roosevelt violated this norm, our nation saw fit to formally constitutionalize the norm by ratifying the Twenty-Second Amendment in $195^{1 . .^{102}}$

Establishing a norm like the de facto Presidential term limit created by George Washington takes a certain level of-let us say-moxie. ${ }^{103}$ I will call this requirement the "moxie test." To start a new norm that people will follow, you have to pass the moxie test. The weightier the norm, the more moxie you need.

Washington easily passes the moxie test. His successors felt compelled to follow his precedent because of who he was. He was the Commander in Chief of the Continental Army. He was the first President of the United States. He was respected by Federalists and Democratic-Republicans alike. And despite all of this, he voluntarily ceded power.

In the context of de facto Supreme Court term limits, the moxie test would ordinarily pose an insurmountable impediment for a single Justice trying to institute term limits through changed norms. Each Justice is one of nine, not one of one like the President. And, even when a Justice builds some moxie over time, their clout usually resides in a particular wing of the Court-think Justice Ginsburg on the left or Justice Scalia on the right.

101. See Calabresi \& Lindgren, supra note $1_{5}$, at $776 \mathrm{n} .3_{0}$ (explaining the de facto Presidential term limit and collecting historical sources); see also Letter from George Washington to Jonathan Trumbull, Jr. (July 2 1, 1 799), https:/ / founders.archives.gov/documents/Washington/o6-o4-o2${ }_{16} 6_{5}$ [https://perma.cc/5 $\mathrm{X}_{24}$-WQAT] (discussing Washington's reasons for not seeking the Presidency in the 1800 election).

102. See U.S. CONST. amend. XXII, $\$ 1$ (establishing that " $[\mathrm{n}]$ o person shall be elected to the office of the President more than twice").

103. I use the term "moxie" to mean "force of character." See Moxie, Google Dictionary, https://www.google.com/search?q=google+dictionary\&oq=google+dictionary\&aqs=chrome..69i 57joi433jol 2 joi 13 1 $_{4} 433 j_{1}{ }_{5} .2765$ joj4\&sourceid=chrome\&ie=UTF-8\#dobs=moxie $[$ https: $/ /$ perm a.cc/TN24-TTJK]. 
Indeed, Calabresi and Lindgren raised the idea that a Justice could implement de facto term limits through changed norms and then dismissed the possibility out of hand.

Such Justices would face a major collective-action problem in trying to persuade their long-serving colleagues to follow their good example. Given the level of partisan hostility on the Supreme Court ... we believe urging a Justice to retire after a set term without regard to strategic considerations would be like unilateral disarmament during the Cold War. There is quite simply very little reason to hope that, if one Justice were to retire early, any other Justice currently on the Court would follow such a good example. In this respect, the Supreme Court is fundamentally different from the Presidency because one President like George Washington or Thomas Jefferson could set a tradition for all succeeding Presidents, whereas one of nine Justices essentially cannot. ${ }^{104}$

In the ordinary course of things, I would be inclined to agree with Calabresi and Lindgren. For the reasons they explain, most Justices could not single-handedly implement term limits through changed norms. However, their analysis overlooks the possibility that the right Justice-a widely-respected (Chief) Justice-could achieve what the vast majority of Justices could not.

Although Chief Justice Roberts is not George Washington, he does have a certain level of moxie. He is the Chief Justice. He is ideologically positioned between the Court's right and left wings. ${ }^{105}$ He commands respect (if not always agreement) from the full ideological spectrum of his colleagues. He is regarded as a committed institutionalist, someone who is willing to place the Court as an institution above his ideological preferences when the moment so requires. ${ }^{106}$

He may well pass the moxie test. What Washington did for the Presidency, Chief Justice Roberts may be able to accomplish for the Supreme Court. His resignation after eighteen years of service could create a norm that his colleagues-both present and future-would feel compelled to follow. This, at least, seems more plausible to me than constitutional amendment or a term-limit statute.

There are two potential criticisms to my proposal that Chief Justice Roberts could create de facto term limits by resigning after eighteen years on the Court. The first is that he would not do it. The second is that even if he did, his colleagues would not follow him.

\footnotetext{
104. Calabresi \& Lindgren, supra note $1_{5}$, at 875 .

105. See John Roberts (Supreme Court), BALLOTPEDIA, https://ballotpedia.org/John_Roberts _(Supreme_Court) [https://perma.cc $\left./ \mathrm{Y}_{7} \mathrm{C}_{7}-\mathrm{SK}_{5} \mathrm{~F}\right]$ (explaining that Justice Roberts has sided with both his conservative and liberal colleagues at different times).

106. See, e.g., Epps \& Sitaraman, supra note 2, at 162 ("Chief Justice Roberts has displayed institutionalist leanings that seem in some cases to push back against his ideological conservatism.").
} 
Early in Chief Justice Roberts' career, while he was an attorney in the Office of White House Legal Counsel under President Reagan, he expressed support for Supreme Court term limits.

The Framers adopted life tenure at a time when people simply did not live as long as they do now. A judge insulated from the normal currents of life for twenty-five or thirty years was a rarity then, but is becoming commonplace today. Setting a term of, say, fifteen years would ensure that federal judges would not lose all touch with reality through decades of ivory tower existence. It would also provide a more regular and greater degree of turnover among the judges. Both developments would, in my view, be healthy ones. ${ }^{107}$

Opinions change with time-and people tend to release convictions previously held about positions of power once they, themselves, come to occupy those positions-so I cannot say with certainty whether the Chief Justice would take the extraordinary action needed to create de facto term limits.

Nor can I say with certainty that Chief Justice Roberts does in fact have the moxie to create de facto term limits through resignation. His clout would face an early test two years after his resignation, when, ideally, the longesttenured Justice then serving on the Court would resign so that Court appointments could be staggered every two years. If two consecutive Justices -including the Chief Justice-resigned to implement de facto term limits, the pressure on the third Justice to follow suit would be immense. That pressure would continue to build as the Justices continue to resign in turn. ${ }^{108}$ Each successive resignation would further entrench the norm.

The second Justice's resignation would thus be critical to establishing de facto term limits. President Washington needed Thomas Jefferson to cede power after two terms. Chief Justice Roberts would need a different Thomas -Justice Clarence Thomas, the Court's longest-tenured member. If Justice Thomas vacates the Court before his resignation would come due in 2025, then the next longest-tenured Justice would be Justice Breyer, who has publicly supported term limits as recently as October 2020. ${ }^{109}$ If both Justices Thomas and Breyer have left the Court by then, Justice Alito would be the most senior Justice remaining. Would Justice Thomas-or Justice Breyer or

107. Memorandum from John G. Roberts to Fred F. Fielding (Oct. 3, 1989), https://digital commons.law.scu.edu/cgi/viewcontent.cgi?article=1110\&context=historical [https://perma.cc $\left./ \mathrm{J} 8 \mathrm{D} 6-\mathrm{V} 8 \mathrm{~L}_{4}\right]$.

108. A Justice who declined to resign may eventually be seen by Congress as failing to maintain "Good Behavior," subjecting them to removal through the impeachment process. Or, if the norm is sufficiently enshrined in practice, its violation may trigger a successful effort to amend the Constitution, a la the Twenty-Second Amendment.

109. See PBS News Hour, Justice Stephen Breyer remembers Ruth Bader Ginsburg: She was a rock, PBS, at 7:10 (Sept. 24, 2020), https://podcasts.apple.com/bf/podcast/justice-stephen-breyer-

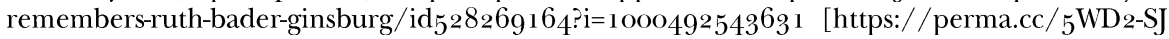
UD] (voicing support for eighteen-year term limits). 
Alito, as the case may be-follow the Chief Justice's lead and resign in 2025? Again, I cannot be certain.

But certainty is not the relevant metric-plausibility is. Other term limit proposals are subject to criticism because they are not plausible. They would require constitutional amendment or would be implemented through statutes that are likely unconstitutional. The question is thus whether the pathway to reform that lies through the Chief Justice is equally or more plausible than constitutional amendment or statutory reform. Might a dedicated institutionalist take extraordinary action to strengthen his institution at a moment of crisis? This does not strike me as any more implausible than the traditional approaches to reform. And it does not strike me as implausible that Chief Justice Roberts' colleagues—on his right and on his left—would follow his lead. He may well pass the moxie test.

\section{CONCLUSION}

The controversy around President Trump's three appointments to the Supreme Court has led to renewed interest in Court reform. Scholars are actively debating and examining different approaches to reform. ${ }^{110}$ Soon a Presidential Commission comprised of 36 Supreme Court experts will try its hand at proposing court reforms (though based on the Commission's size and ideological composition, it seems exceedingly unlikely that it will reach agreement on a reform).$^{111}$

Reforms based on changed norms, rather than constitutional or statutory changes, have been largely absent from this conversation. Given the practically insurmountable barriers to constitutional or statutory reform, this omission is a mistake. Thus, I add to the existing menu of statutory and constitutional reforms a different approach: Convince Chief Justice Roberts that the best way to strengthen the institution he cares so deeply about is to resign after eighteen years and to persuade his colleagues to follow suit. That pathway to term limits, at the least, seems no more tortuous than the others.

1 10. See, e.g., Epps \& Sitaraman, supra note 2; Sachs, supra note 4o; Daniel Epps \& Ganesh Sitaraman, Supreme Court Reform and American Democracy, 1 go YALE L.J. ForUM 821 (Mar. 8, 2021); Adam Chilton, Daniel Epps, Kyle Rozema, \& Maya Sen, Designing Supreme Court Term Limits, S. CAL. L. REV. (forthcoming).

1 11. See President Biden to Sign Executive Order Creating the Presidential Commission on the Supreme Court of the United States, THE WHITE HOUSE (Apr. 09, 2021), https://www.whitehouse.gov /briefing-room/statements-releases/202 1/04/og/president-biden-to-sign-executive-order-creat ing-the-presidential-commission-on-the-supreme-court-of-the-united-states/ [https://perma.cc /KJ35-2PUF] (announcing the Commission's formation and identifying the Commission's $3^{6}$ members). 